\title{
Mechanisms to Manage the Regional Socio-Economic Development and Efficiency of the Decentralization Processes
}

\author{
Inna Irtyshcheva ${ }^{1}$, Iryna Kramarenko ${ }^{2}$, Taras Vasyltsiv ${ }^{3}$, Yevheniya Boiko ${ }^{1}$, \\ Olena Panukhnyk ${ }^{4}$, Nataliya Hryshyna ${ }^{1}$, Oryslava Hrafska ${ }^{5}$, Olena Ishchenko ${ }^{1}$, \\ Nataliya Tubaltseva $^{1}$, Ihor Sirenko ${ }^{1}$, Nazariy Popadynets ${ }^{3(\bowtie)}$, and Iryna Hryhoruk ${ }^{6}$ \\ 1 Admiral Makarov National University of Shipbuilding, Heroyiv Ukrayiny Ave. 9, \\ Mykolayiv 54025, Ukraine \\ 2 Mykolaiv Interregional Institute of Human Development of the University "Ukraine”, \\ Viyskova Street 22, Mykolayiv 54000, Ukraine \\ ukraina_09@ukr.net \\ 3 State Institution "Institute of Regional Research named after M. I. Dolishniy \\ of the NAS of Ukraine", Kozelnytska, Street 4, Lviv 79026, Ukraine \\ tgvas77@ukr.net \\ 4 Ternopil Ivan Puluj National Technical University, \\ Bilogirska, Street 50, Ternopil 46001, Ukraine \\ 5 I. Boberskyi Lviv State University of Physical Culture, \\ Kostiushko, Street 11, Lviv 79000, Ukraine \\ 6 Vasyl Stefanyk Precarpathian National University, Shevchenko, Street 57, \\ Ivano-Frankivsk 76018, Ukraine
}

\begin{abstract}
The process of administrative and territorial reform in Ukraine urges most of the population to think about their future because the finalization of the reform stipulates that local governments are independent, and residents are responsible for their territories. To finish the process of administrative reform, it is necessary to efficiently use resources to achieve the ultimate decentralization objective. The paper aims to evaluate the efficiency of decentralization as an essential tool for the socio-economic development of regions. The efficiency of the reform implementation in Ukrainian regions is suggested to be evaluated across the organizational-administrative and budgetary components. The parameters of analysis of the reform implementation efficiency in the regions across the suggested components are systematized. The absence of a consistent relationship between the organizational-administrative and budgetary components is confirmed.
\end{abstract}

Keywords: Management mechanisms · Authorities' decentralization · Financial decentralization - Administrative division

\section{Introduction}

Development of operative instruments to evaluate the efficiency of transformation processes for the purpose of improving their controllability for securing sustainable economic and social development of the country remains to be one of the most important 
issues at the current stage of transformation of the national socio-economic system and managerial institutes under the impact of geopolitical changes, globalization processes, and implementation of the decentralization reform.

However, currently, the single criteria to complexly evaluate the efficiency of decentralization processes are lacking. Since the processes have lasted for decades in most countries, the short-term results displayed at the level of regions, the more so the country, can hardly be expected. However, some aspects of improvement (deterioration) of the regions' or territorial communities' socio-economic condition caused by the transformation of the systems of regional and local finances management in 2015-2018 in the context of certain reform efficiency indicators at the current stage of its implementation should be recorded and researched, and the respective decisions should be made.

It is worth mentioning that national ministries and administrations, departments of State Statistical Service of Ukraine, scientific institutions and organizations analyze and monitor various aspects of the decentralization reform implementation and the level of socio-economic development of Ukrainian regions. However, the complex analysis that determines and compares organizational, financial, and social results of the reform at various stages of its implementation does not get proper attention. In this context, the authors suggest improving the methodological approaches to evaluation of the reform efficiency based on the combination of the structural changes methodology and integral analysis.

According to Buhil S.Y., the peculiar feature of the current model in Ukraine is that in the course of integration with the EU countries, its budgetary and tax legislation is changing and is supplemented in the context of European standards of economy reforming in terms of local governments activity and decentralization of the financial system with the view to stimulate the development of local communities [1]. Therefore, many scientific studies are devoted to the issues of implementation of organizational, financial, and social aspects of the reform and their legal, economic, and social estimation. In particular, the complex analysis of the processes of decentralization implementation at all managerial levels is conducted by Kasych and Petrushko [2]. The impact of the financial decentralization on the condition of local budgets in Ukraine was examined by [3-7]. A team of leading scientists of the State Institution "The Institute of Regional Research Named after M. I. Dolishniy of the NAS of Ukraine" substantiates the methodological approaches and results of the evaluation of decentralization in Ukraine and its impact on socio-economic development of territories [8-11]. Boryslavska et al. consider decentralization as expansion and strengthening of the rights of territorial communities to address local issues and accomplish their tasks within the limits established by the law and under the responsibility of authorized bodies and officials [12]. Shevchuk in the nature of decentralization provides broader liabilities and managerial functions to authorities that do not belong to the system of executive authorities and are relatively independent of it [13]. Tkachuk actually equals it with local governments [14]. Braun von J. and U Grote take the attitude that decentralization stipulates the extended competences of local administrative authorities and transfer of liabilities and responsibilities for the implementation of public functions from the central government to the subordinate local governments. O. M. Boryslavska et al. argue that decentralization of authorities also provides for the extended circle of tasks and functions implementation entities that 
are of public nature, not being limited to the level of territorial units and thus - local governments [12]. Moreover, decentralization envisages the division of competences and specification of liabilities not only vertically (clear decision-making procedure for managerial bodies at various levels), but also horizontally (distributing and determining functions and competences of all other elements in the structure of public administrative authorities, excluding the managerial body).

The paper aims to evaluate the efficiency of decentralization as an essential tool for the socio-economic development of regions.

\section{Methodology}

Two main directions of the decentralization process are taken into account to evaluate the efficiency of the authorities' decentralization reform, namely:

- Organizational-administrative. Its nature shows in the reformatting of the system of territories' management based on their consolidation and forming new managerial competencies. Quality and pace of communities' consolidation and obtaining by them of respective managerial competencies that correspond to the requirements of administrative-territorial reform are the criteria of the efficiency of organizational-administrative processes.

- Financial. The redistribution of budget flows to expand the financial basis of territorial communities to organize their socio-economic development is its key criteria. The efficiency of this direction lies in the capacity of territorial budgets in terms of funding the major статей витрат of the community, reduction of the subsidiarity level, and improvement of investment activity of the territory.

\section{Results and Discussion}

To evaluate the organizational-administrative efficiency, the complex indicator of the organizational efficiency of the decentralization processes in 2015-2018 across the regions of Ukraine is calculated (Table 1).

Therefore, taking into account the complex efficiency rate, the highest level of structural changes in terms of the reform implementation (over 70\%) is peculiar to Zhytomyrska, Chernihivska, Zaporizka, Volynska, and Sumska oblasts. The lowest rates $(30 \% \leq)$ are in Zakarpatska, Lvivska, and Kyivska oblasts.

Evaluation of the budgetary efficiency of the administrative-territorial reform implementation is the next stage of our research. According to the calculations (Table 2), we see that Zakarpatska oblast was the only one to match the criterion in 2015. In 2016, the number of oblasts where the income growth index exceeded the budgetary transfers growth index increased to 5 oblasts, namely Volynska, Zakapatska, Ternopilska, and Chernivetska. As of late 2017, the criterion was matched by almost all regions, excluding Luhanska oblast. In 2018, the rate fell below the standardized value in the range of oblasts, which is explained, in the first place, by reduced fiscal efficiency of local governments. 
Table 1. Calculation of the complex indicator of the organizational efficiency of the decentralization processes implementation in Ukrainian regions in 2015-2018

\begin{tabular}{|c|c|c|c|c|c|c|c|}
\hline \multirow[t]{2}{*}{$\begin{array}{l}\text { Regions of the } \\
\text { country }\end{array}$} & \multicolumn{3}{|c|}{$\begin{array}{l}\text { Indices of structural } \\
\text { changes }\end{array}$} & \multicolumn{3}{|c|}{ Standardized indices } & \multirow{2}{*}{$\begin{array}{l}\text { Complex } \\
\text { indicator of } \\
\text { organizational } \\
\text { efficiency* } \\
\text { ED }\end{array}$} \\
\hline & $I_{C T C}$ & $I_{P}$ & $I_{A}$ & $N_{I_{C T C}}$ & $N_{I_{P}}$ & $N_{A}$ & \\
\hline Vinnytska & 16.7 & 38.0 & 16.2 & 0.3 & 0.6 & 0.3 & 40.3 \\
\hline Volynska & 48.5 & 29.0 & 43.6 & 0.9 & 0.5 & 0.7 & 77.1 \\
\hline Dnipropetrovska & 41.6 & 8.0 & 45.5 & 0.8 & 0.1 & 0.7 & 57.8 \\
\hline Donetska & 26.0 & 5.0 & 1.2 & 0.5 & 0.1 & 0.0 & 36.2 \\
\hline Zhytomyrska & 53.5 & 52.0 & 50.3 & 1.0 & 0.9 & 0.8 & 94.9 \\
\hline Zakarpatska & 3.9 & 5.5 & 3.9 & 0.1 & 0.1 & 0.1 & 7.8 \\
\hline Zaporizka & 54.1 & 24.9 & 60.7 & 1.0 & 0.4 & 1.0 & 82.3 \\
\hline Ivano-Frankivska & 23.8 & 26.8 & 25.3 & 0.4 & 0.4 & 0.4 & 44.1 \\
\hline Kyivska & 15.1 & 21.2 & 18.0 & 0.3 & 0.3 & 0.3 & 30.0 \\
\hline Kirovohradska & 13.4 & 14.9 & 20.1 & 0.2 & 0.2 & 0.3 & 24.7 \\
\hline Luhanska & 38.0 & 6.0 & 30.0 & 0.7 & 0.1 & 0.5 & 52.2 \\
\hline Lvivska & 14.4 & 4.0 & 15.1 & 0.3 & 0.1 & 0.2 & 20.7 \\
\hline Mykolayivska & 43.8 & 22.5 & 39.4 & 0.8 & 0.4 & 0.6 & 67.8 \\
\hline Odeska & 19.7 & 6.9 & 22.4 & 0.4 & 0.1 & 0.4 & 28.9 \\
\hline Poltavska & 24.4 & 20.7 & 22.4 & 0.5 & 0.3 & 0.4 & 41.8 \\
\hline Rivnenska & 26.0 & 20.1 & 26.6 & 0.5 & 0.3 & 0.4 & 43.6 \\
\hline Sumska & 38.5 & 60.8 & 39.3 & 0.7 & 1.0 & 0.6 & 79.8 \\
\hline Ternopilska & 20.5 & 38.0 & 32.1 & 0.4 & 0.6 & 0.5 & 45.3 \\
\hline Harkivska & 17.2 & 12.0 & 20.9 & 0.3 & 0.2 & 0.3 & 28.2 \\
\hline Hersonska & 33.9 & 27.2 & 31.6 & 0.6 & 0.4 & 0.5 & 57.3 \\
\hline Hmelnytska & 28.8 & 30.0 & 42.9 & 0.5 & 0.5 & 0.7 & 52.0 \\
\hline Cherkaska & 34.6 & 24.4 & 34.9 & 0.6 & 0.4 & 0.6 & 56.8 \\
\hline Chernivetska & 29.9 & 28.2 & 34.5 & 0.6 & 0.5 & 0.6 & 52.6 \\
\hline Chernihivska & 49.8 & 39.8 & 52.1 & 0.9 & 0.7 & 0.9 & 84.1 \\
\hline
\end{tabular}

* - weight coefficients to calculate the complex indicator were selected by expertize and amount to $N_{I_{C T C}}=0.4 ; N_{I_{P}}=0.3 ; N_{A}=0.3$

Source: developed by the author based on data [15]

Table 3 provides the share of oblast's income in the structure of regional budgets in 2015 and 2018, the calculated autonomy growth index and its standardized value, the 
Table 2. Dynamics of income growth index against the central budgets' transfers across Ukrainian regions and standardized values in 2018

\begin{tabular}{llllll}
\hline Regions of Ukraine & 2015 & 2016 & 2017 & 2018 & $\begin{array}{l}\text { Standardized } \\
\text { values, NRF }\end{array}$ \\
\hline Vinnytska & 98.2 & 88.6 & 128.9 & 101.6 & 0.90 \\
Volynska & 95.8 & 113.8 & 124.9 & 110.4 & 0.98 \\
Dnipropetrovska & 92.9 & 62.2 & 123.2 & 93.5 & 0.83 \\
Donetska & 74 & 65.3 & 127.2 & 90.6 & 0.80 \\
Zhytomyrska & 99.7 & 90.6 & 124.5 & 102.6 & 0.91 \\
Zakarpatska & 101.8 & 104.8 & 136 & 110.7 & 0.98 \\
Zaporizka & 95.1 & 74.6 & 136.8 & 88.4 & 0.78 \\
Ivano-Frankivska & 93.9 & 97.1 & 118.8 & 100.5 & 0.89 \\
Kyivska & 86.6 & 82.9 & 136.4 & 99.6 & 0.88 \\
Kirovohradska & 99.3 & 85.9 & 129.8 & 99.9 & 0.89 \\
Luhanska & 79.2 & 86.9 & 96.5 & 101.5 & 0.90 \\
Lvivska & 95.9 & 91.5 & 139.5 & 95.3 & 0.85 \\
Mykolayivska & 95.3 & 87.8 & 135.5 & 99.4 & 0.88 \\
Odeska & 91 & 88.6 & 148.1 & 112.7 & 1.00 \\
Poltavska & 84 & 74.4 & 115.7 & 96.6 & 0.86 \\
Rivnenska & 93.8 & 92.4 & 123.1 & 105.7 & 0.94 \\
Sumska & 92 & 81 & 118.8 & 108.9 & 0.97 \\
Ternopilska & 93 & 102.8 & 109.4 & 106 & 0.94 \\
Harkivska & 76.1 & 85.6 & 130.9 & 96.2 & 0.85 \\
Hersonska & 96.8 & 99 & 130.9 & 100.2 & 0.89 \\
Hmelnytska & 94.7 & 95.3 & 122 & 99.3 & 0.88 \\
Cherkaska & 88.4 & 90.6 & 121.3 & 95.9 & 0.85 \\
Chernivetska & 89.8 & 105.5 & 133.2 & 88.3 & 0.78 \\
Chernihivska & 94.2 & 93.5 & 130.3 & 93.2 & 0.83 \\
\hline Sourc: devaped & & & &
\end{tabular}

Source: developed by the author based on data [15]

ratio of regional capital investment to capital investment in the region from the public budget, and standardized values.

The calculations show that in 2015-2018, the share of income in the structure of regional budgets grew in all oblasts, excluding Luhanska. The highest pace of autonomy growth index was in Odeska oblast $(12.7 \%)$, where the share of income amounted to $54.76 \%$ in 2018 . The highest level of oblast budget dependence on the central one (over 65\%) was observed in the oblasts of the Western region, namely Ternopilska, Ivano-Frankivska, Rivnenska, Zakarpatska, and Volynska.

In 2018, the weight of investment from regional budget averagely exceeded the weight of capital investment in the development forwarded to the regions from the public budget and was over 1.05 p.p. in 11 oblasts. The leading positions among them are occupied by Luhanska (2.50), Sumska (1.65), Vinnytska (1.55), and other oblasts. Compared to 2015, the number of oblasts with prevailing regional investment increased by 6 , which testifies to certain positive results of the decentralization reform implementation.

However, in some regions (Kyivska, Donetska, Zaporizka, Ivano-Frankivska, Lvivska, and Mykolayivska), the index of structural changes in capital investment is negative. These rates testify to either additional resources forwarded to the region from the public budget for capital investment in 2018 (including the development of road 
Table 3. Calculation of the regional budget autonomy growth index and regional development capital investment index

\begin{tabular}{l|l|l|l|l|l|l|l|r}
\hline $\begin{array}{l}\text { Regions of } \\
\text { Ukraine }\end{array}$ & 2015 & 2018 & $\begin{array}{l}\text { Autonomy } \\
\text { index, } \%\end{array}$ & $\begin{array}{l}\text { Standardized } \\
\text { values, } \mathrm{N}_{\mathrm{BA}}\end{array}$ & 2015 & 2018 & \multicolumn{1}{l}{ Ic } & \multicolumn{1}{l}{$\mathrm{N}_{\mathrm{C}}$} \\
\hline Vinnytska & 33.6 & 39.89 & 6.3 & 0.49 & 0.3 & 1.55 & 1.25 & 0.94 \\
\hline Volynska & 27.8 & 34.67 & 6.9 & 0.54 & 0.27 & 0.76 & 0.49 & 0.37 \\
\hline Dnipropetrovska & 50.1 & 53.58 & 3.5 & 0.28 & 0.97 & 1.64 & 0.67 & 0.50 \\
\hline Donetska & 42.8 & 46.26 & 3.5 & 0.28 & 1.29 & 1.28 & -0.01 & -0.01 \\
\hline Zhytomyrska & 31.0 & 36.42 & 5.5 & 0.43 & 0.12 & 0.65 & 0.53 & 0.40 \\
\hline Zakarpatska & 24.6 & 32.89 & 8.3 & 0.66 & 0.40 & 0.81 & 0.41 & 0.31 \\
\hline Zaporizka & 44.1 & 48.48 & 4.4 & 0.34 & 0.70 & 0.46 & -0.24 & -0.18 \\
\hline Ivano-Frankivska & 26.3 & 29.84 & 3.6 & 0.28 & 1.05 & 0.81 & -0.24 & -0.18 \\
\hline Kyivska & 45.1 & 52.77 & 7.6 & 0.60 & 5.68 & 0.72 & -4.96 & -3.73 \\
\hline Kirovohradska & 34.4 & 40.43 & 6.1 & 0.48 & 0.30 & 0.89 & 0.59 & 0.44 \\
\hline Luhanska & 39.9 & 39.37 & -0.5 & -0.04 & 1.17 & 2.50 & 1.33 & 1.00 \\
\hline Lvivska & 34.8 & 41.48 & 6.7 & 0.53 & 0.97 & 0.63 & -0.34 & -0.26 \\
\hline Mykolayivska & 36.4 & 43.54 & 7.1 & 0.56 & 0.78 & 1.47 & 0.69 & 0.52 \\
\hline Odeska & 42.0 & 54.76 & 12.7 & 1.00 & 1.10 & 0.60 & -0.50 & -0.38 \\
\hline Poltavska & 43.5 & 46.3 & 2.8 & 0.22 & 0.8 & 0.89 & 0.06 & 0.05 \\
\hline Rivnenska & 25.8 & 31.08 & 5.3 & 0.42 & 0.4 & 0.76 & 0.40 & 0.30 \\
\hline Sumska & 34.6 & 40.58 & 6.0 & 0.47 & 0.4 & 1.65 & 1.24 & 0.93 \\
\hline Ternopilska & 25.7 & 28.68 & 2.9 & 0.23 & 0.2 & 1.10 & 0.91 & 0.68 \\
\hline Harkivska & 42.7 & 48.36 & 5.7 & 0.45 & 0.7 & 0.94 & 0.27 & 0.20 \\
\hline Hersonska & 32.4 & 38.57 & 6.2 & 0.49 & 0.2 & 1.26 & 1.02 & 0.77 \\
\hline Hmelnytska & 31.7 & 36.01 & 4.3 & 0.34 & 0.7 & 1.05 & 0.32 & 0.24 \\
\hline Cherkaska & 35.9 & 39.45 & 3.6 & 0.28 & 0.7 & 1.11 & 0.42 & 0.32 \\
\hline Chernivetska & 27.2 & 30.47 & 3.3 & 0.26 & 0.5 & 0.79 & 0.27 & 0.20 \\
\hline Chernihivska & 33.8 & 38.29 & 4.5 & 0.35 & 0.4 & 1.09 & 0.68 & 0.51 \\
\hline Source: & & & & & & & & \\
\hline
\end{tabular}

Source: developed by the author based on data [15]

infrastructure) or reduced volumes of local development funds. In this regard, the situation in each oblast is different, thus showing the ambiguousness and lack of unified methods of financial decentralization that will equally efficiently work in various regions.

Calculating the efficiency of structural changes in financial and budgetary domains of the regions under the impact of decentralization processes is another important factor of decentralization (Fig. 1).

According to the results of calculations, Kyivska oblast demonstrated the negative rate in 2018 compared to 2015. The negative value is caused, in the first place, by falling 


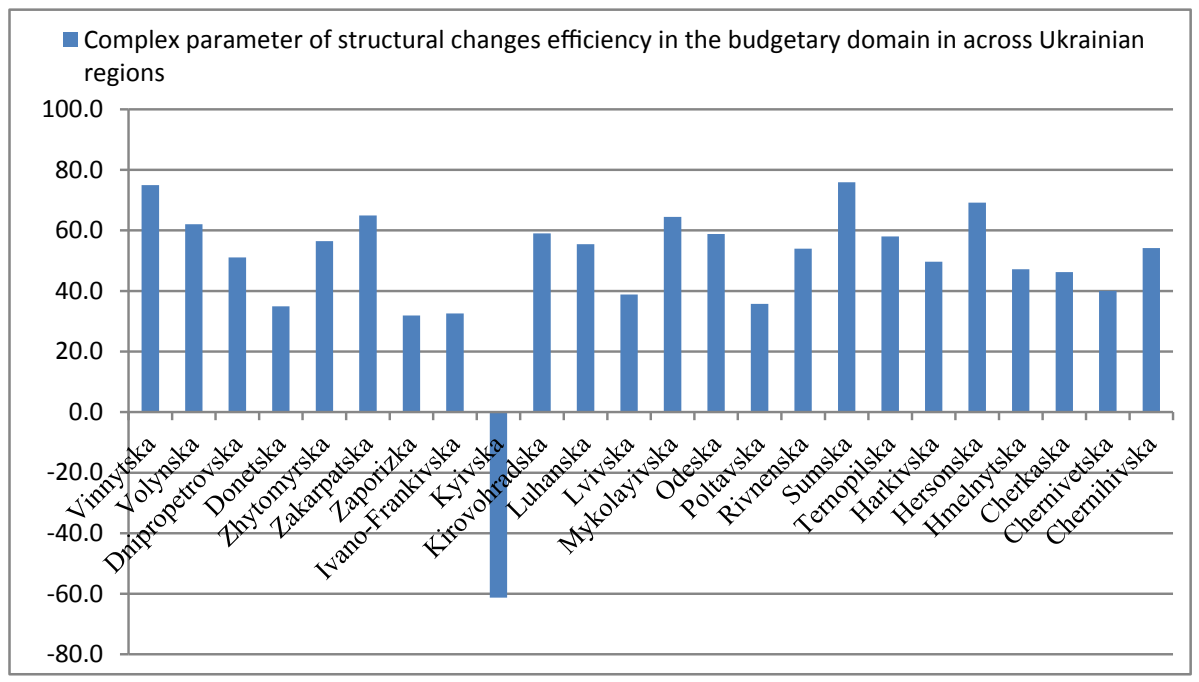

Fig. 1. Complex parameter of structural changes efficiency in the budgetary domain in 2015-2018 across Ukrainian regions, \%. Source: developed by the author based on data [15]

share of capital investment from the regional budget against the background of growing capital investment of the region from the public budget. It can testify not only to a low level of budget efficiency but also funding of large-scale public projects that are of national importance at the territory of the region. In other regions, the comparative efficiency of structural changes ranges from 20 to $80 \%$. In general, it can testify to some growth of budget autonomy of the regions in the analyzed period and growing resources of their development.

\section{Conclusions}

The parameters of analysis of the reform implementation efficiency in the regions across the organizational-administrative and budgetary components are systematized. They can be used to determine the average pace of the reform implementation in the country and to conduct a comparative analysis of the respective structural changes. The analysis of the efficiency of the decentralization reform implementation across the regions of Ukraine shows that a consistent relationship between the organizational-administrative and budgetary results of the reform in the regions is absent. The processes remain to be unbalanced due to slow reform implementation in some regions, existing unsolved contradictions, duplication of some managerial functions, and insufficient level of citizens' confidence in authorities.

\section{References}

1. Bugil, S.Ya.: Priorities of financial decentralization in ensuring sustainable development of territorial communities of Ukraine. Black Sea Econ. Stud. 28(2), 84-87 (2018) 
2. Kasich, A.O., Petrushko, A.S.: Management of decentralization processes: foreign experience and strategic objectives for Ukraine. Econ. Soc. 13, 71-77 (2017)

3. Voznyak, H., Panukhnyk, O., Khymych, H., Popadynets, N.: Development of regional economic systems under the impact of financial decentralization: display, challenges and new opportunities. In: Advances in Economics, Business and Management Research, MDSMES 2019, pp. 121-126 (2019). https://doi.org/10.2991/mdsmes-19.2019.24

4. Siryk, Z.O.: Financial decentralization as a precondition of increasing the capacity of local governments in Ukraine. Soc.-Econ. Probl. Mod. Period Ukraine: Collect. Sci. Papers 1(141), 10-20 (2020)

5. Vasyltsiv, T.H. (ed.): Financial Mechanisms and Instruments of Overcoming the Misbalances of Socio-Economic Development of Ukraine. Publishing House TzOV «Liha-Pres», Lviv (2016)

6. Parubets, O.M., Sugonyako, D.O., Parubets, M.S.: Research of influence of reform of financial decentralization on a condition of local budgets of Ukraine. Effective economy, vol. 5 (2017). http://www.economy.nayka.com.ua/?, op $=1 \& \mathrm{z}=5593$

7. Oleksyuk, H., Lysyak, N., Popadynets, N.: Conceptual and structural models of endogenous capacity of the consolidated territorial communities as a precondition for increasing their competitiveness. Econ. Ukraine 3, 52-69 (2019). https://doi.org/10.15407/economyukr.2019. 03.052

8. Kravtsiv, V.S. (ed.): Administrative-territorial structure of Ukraine: methodological foundations and practice of reforming, Lviv (2016)

9. Kravtsiv, V.S. (ed.): Territorial communities in condition of decentralization: risks and development mechanisms: monograph, Lviv (2020)

10. Hrynchyshyn, I.M., Bil, M.M., Leshchuh, I.V., Patytska, H.O., Popadynets, N.M.: Growing capacity of territorial communities based on efficient use of the endogenous capacity, Lviv (2019)

11. Zhuk, P.: Up-to-day issues and ways of administrative and territorial system reforming in Ukraine. Soc.-Econ. Probl. Mod. Period Ukraine 1(111), 20-25 (2015)

12. Boryslavska, O.M., Zaveruha, I.B., Shkolyk, A.M.: Decentralization of public authorities: experience of European countries and perspectives of Ukraine. Center of Political-Legal Reforms, Kiev (2012)

13. Shevchuk, B.M.: Decentralization. Encyclopedia of Public Governance. LRIDU NADU, Lviv (2011)

14. Tkachuk, A.: Local governance and decentralization. In: Practical Handbook; SwissUkrainian Project "Decentralization Support in Ukraine - DESPRO". TOV "Sofiya”, Kiev (2012)

15. The official site of State Statistics Service of Ukraine (2020). https://ukrstat.org/en/operativ/ oper_new_e.html 